\title{
Feeding Broccoli Floret Residues on Layers: II. Effects on Fatty Acid Deposition
}

\author{
A.F. Mustafa* \\ Department of Animal Science, McGill University, Sta-Anne-De-Bellevue, H9X 3 V9, QC. Canada
}

${ }^{\star}$ Corresponding author: A.F. Mustafa, Department of Animal Science, McGill University, Sta-Anne-De-Bellevue, H9X 3 V9, QC. Canada; E-mail: arif.mustafa@mcgill.ca

Received: May 03, 2019; Accepted: May 09, 2019; Published: May 21, 2019;

\begin{abstract}
A study was conducted to determine the effects of feeding Dried Broccoli Florets (DBF) to layers on egg yolk fatty acid deposition. Seventy-two layers were randomly allotted to four dietary treatments (six cage replicates with three hens each) and fed diets containing $0,4,8$, and $12 \%$ DBF for 56 days. Results showed that inclusion of DBF decreased (linear effect, $P<0.001$ ) concentrations of Saturated Fatty Acids (SFA) and increased (linear effect, $P<$ 0.001 ) concentrations of poly-unsaturated fatty acids (PUFA). Egg yolk concentration of palmitic acid decreased (linear effect, $P<0.001)$ while linoleic (quadratic effect, $P=0.003$ ) and linolenic (linear effect, $P<0.001$ ) acid concentrations increased as the level of DBF in the diet increased. It was concluded that feeding DBF at $12 \%$ of the diet increased PUFA concentrations and decreased those of SFA.
\end{abstract}

\section{Introduction}

Broccoli (Brassica oleracea L. var. italica) is an important vegetable crop in Canada with an annual production of 32,000 tons. As with other vegetables, large amounts of broccoli wastes are generated during harvest, packaging and marketing. It has been estimated that about 40 to $50 \%$ of total broccoli produced is discarded during processing as a result of the high standards imposed by consumers and retailers, and due to consumer refusal at the retail level. Additional losses occur in the field, generating large quantities of florets, stems and leaves as crop residues. As broccoli production increases, there is a concomitant increase in the quantity of residues produced. These residues are often discarded into the environment where they pose major environmental concerns. There is growing interest in developing new feeds from waste vegetable such as broccoli by-products to replace conventional feeds. Recent research showed that broccoli residues such as broccoli leaves and stems and broccoli florets can be incorporated in layer diets to substitute conventional feeds such as soybean meal. Incorporation of dried broccoli leaves and stems up to $9 \%$ of the diets had no effect on egg production, but significantly improved egg quality with higher yolk xanthophyll and lower yolk cholesterol concentrations [1], In more recent study, [2] reported that feeding Dried Broccoli Florets (DBF) up to $12 \%$ of the diet had no negative effects on feed intake, egg production and feed efficiency and improve egg yolk color and a-tocopherol. Chemical analysis of different broccoli parts showed that florets contained higher CP (22.4\%) but lower crude fiber (11.7\%) concentrations than broccoli leaves and stems [3]. Broccoli florets are also a rich source of poly-unsaturated fatty acids which constitute $62 \%$ of the total fatty acids [3]. Inclusion of feeds rich in PUFA has been shown to increase n-3 PUFA deposition in egg yolks without compromising egg production [4-6]. To the best of our knowledge, no studies have investigated the effects of dried broccoli floret (DBF) residues on egg yolk fatty acid profile.

\section{Materials and Methods}

\section{Birds and housing}

All animal procedures were approved by the Animal Care Committee of the Faculty of Agricultural and Environmental Sciences of McGill University. This study was part of larger study in evaluating the effects of feeding DBF on layer performance and total tract nutrient retention [2]. Preparation, processing and chemical composition were reported [2]. A Total of 72 (64-week-old) White Leghorn laying hens were weighed and placed in 24 cages (3 birds/cage) with six cage replicates. Each cage representing one replicate, was assigned to one of four experimental diets containing 0, 4, 8 and 12\% DBF for 56 days. Dried broccoli florets partially replaced corn and soy bean meal (Table 2). All diets were formulated to be iso-caloric and iso-nitrogenous according to [7] and were offered in a mash form. Feed and water were provided ad libitum. Birds. Birds received equal daily lighting time (16L: 8D) at constant room temperature.

\section{Sample collection}

Feed intake was measured by-weekly. Two eggs from each cage replicates were collected at random, cracked, and yolks were separated from the whites. Samples of pooled egg yolks (2 eggs/cage replicates/ treatment) for each treatment were collected at week $2,4,6$, and 8 of the experiment $(n=48)$. The yolk samples were frozen at $-20{ }^{\circ} \mathrm{C}$, freeze dried, and finely ground before fatty acid analysis. Methyl esters of fatty acids were prepared from yolk, feed, and DBF samples according to [8]. Acid composition of methyl esters was determined by gas chromatography as described by [6]

\section{Statistical Analysis}

Data were analyzed using the PROC MIXED procedure [9] with the following model: 


\section{$Y i j k=\mu+T i+C i j+e i j k$}

Where: $\mathrm{Y}_{\mathrm{ijk}}=$ observation, $\mu=$ overall mean,

$\mathrm{T}_{\mathrm{i}}=$ fixed effect of $\mathrm{i}^{\text {th }}$ treatment $(\mathrm{i}=1,2,3$ or 4$)$,

$\mathrm{C}_{\mathrm{ij}}=$ random effect of $\mathrm{j}^{\text {th }}$ cage within $\mathrm{i}^{\text {th }}$ treatment $(\mathrm{j}=1,2,3,4,5$ or 6),

$\mathrm{e}_{\mathrm{ijk}}=$ residual error $(\mathrm{k}=1$ or 2$)$,

$$
\mathrm{e}_{\mathrm{ijk}} \sim \mathrm{N}(0, \sigma 2 \mathrm{e}) \text {. }
$$

The least significant difference method was used to identify statistically different means $(P<0.05)$. Orthogonal contrasts were used to test for linear and quadratic effects of adding DBF to the diet. The least square mean method was used to identify differences among treatment means and statistical differences were declared at $\mathrm{p}<0.05$.

Data were analyzed by one-way ANOVA using the GLM procedure [9] with cages as experimental units. Least significant difference method was used to identify statistically different means $(P<0.05)$. Orthogonal contrasts were used to test for linear and quadratic effects of adding DBF to the diet.

\section{Results}

Linolenic acid (C18: 3n3) was the most abundant fatty acid followed by palmitic and oleic acid, respectively (Table 2). Dietary C18: 3 n 3 increased by $8.2,24.5$, and $61.2 \%$ as BDF increased by 4,8 , and $12 \%$, respectively (Table 1 ).

Saturated (SFA) and mono-unsaturated (MUFA) fatty acids of egg yolk decreased (linear effect, $P<0.0001$ ) with increasing dietary DBF (Table 5). The reductions in SFA and MUFA were mainly due to the declines in palmitic (quadratic effect, $P=0.0838$ ) and oleic (linear effect, $P<0.0001)$ acids, respectively. In contrast, poly-unsaturated fatty acid (PUFA) concentrations in egg yolk increased (linear effect, $P<0.0001)$ as the level of dietary DBF increased.

Consequently, SFA: PUFA ratio decreased (linear effect, $P<$ 0.0001 ) in yolks produced by layers fed DBF. As the level of dietary DBF increased, yolk linolenic acid content (quadratic effect, $P=0.011$ ) with highest concentrations being achieved for layers fed 8 and $12 \%$ DBF diets. A similar increase in yolk linoleic (linear effect, $P<0.0001$ ) content was also observed as the level of dietary DBF increased.

\section{Discussion}

Linolenic acid concentration of DBF constitutes $35.4 \%$ of the total fatty acids, which is consistent with the values reported for broccoli florets $[9,10]$, The Fatty acid profile of egg yolk reflected the dietary fatty acid composition. The increase in PUFA and linolenic acid concentrations is likely due to the high levels of linolenic acid concentration in DBF-based diets (Table 1) and DBF (Table 2). Inclusion of $\mathrm{DBF}$ at 4,8 , and $12 \%$ of the diet were accompanied with significant increases (i.e. 23.3, 66.3, and $68.6 \%$, respectively) in egg yolk deposition of linolenic acid when compared with the control diet. Feeding layers diets rich in linolenic acid such as cabbage residues [11], pasture [12], and flaxseed [4, 6] has been successfully used to increase the concentration of linolenic acid as well as other health promoting fatty acids in egg yolk. The lower egg yolk SFA and MUFA concentrations produced by layers fed DBF diets can be attributed to their lower concentrations in DBF diets and $\backslash$ or the inhibitory effects of PUFA. It is well documented that PUFA inhibit the activity of ${ }^{9} \Delta$ desaturase which is involved in MUFA synthesis [13, 14].

\section{Conclusions}

It was concluded that incorporation of DBF in layer diets reduced egg yolk concentrations of SFA and increased those of PUFA. Greater deposition of omega-3 fatty acids (e.g. C18: 3 n3) can be achieved by 6 or $9 \%$ DBF.

Table 1. Ingredients and chemical composition of dietary treatments

\begin{tabular}{|c|c|c|c|c|}
\hline & \multicolumn{4}{|c|}{ Broccoli floret residue inclusion (\%) } \\
\hline & 0.0 & 4.0 & 8.0 & 12.0 \\
\hline \multicolumn{5}{|l|}{ Ingredients (\%) } \\
\hline Corn & 53.68 & 51.64 & 49.61 & 47.57 \\
\hline Soybean & 31.47 & 29.10 & 26.73 & 24.37 \\
\hline Dried broccoli floret residues & 0.0 & 4.00 & 8.00 & 12.00 \\
\hline Limestone & 10.31 & 10.29 & 10.27 & 10.25 \\
\hline Soybean oil & 2.18 & 2.61 & 3.04 & 3.47 \\
\hline Mono-calcium phosphate & 1.25 & 1.22 & 1.20 & 1.17 \\
\hline Mineral-vitamin $\operatorname{mix}^{1}$ & 0.50 & 0.50 & 0.50 & 0.50 \\
\hline Salt & 0.27 & 0.28 & 0.29 & 0.30 \\
\hline Choline chloride & 0.10 & 0.10 & 0.10 & 0.10 \\
\hline Sodium carbonate & 0.08 & 0.08 & 0.08 & 0.08 \\
\hline Methionine & 0.01 & 0.02 & 0.03 & 0.04 \\
\hline \multicolumn{5}{|l|}{ Calculated analysis } \\
\hline $\begin{array}{l}\text { Metabolizable energy (kcal/ } \\
\mathrm{kg} \text { ) }\end{array}$ & 2775.00 & 2775.00 & 2775.00 & 2775.00 \\
\hline Crude protein $(\%)$ & 19.00 & 19.00 & 19.00 & 19.00 \\
\hline Total lysine, (\%) & 1.10 & 1.10 & 1.10 & 1.10 \\
\hline Total methionine (\%) & 0.30 & 0.30 & 0.30 & 0.30 \\
\hline Total Ca $(\%)$ & 4.30 & 4.30 & 4.30 & 3.00 \\
\hline Total P (\%) & 0.60 & 0.60 & 0.60 & 0.60 \\
\hline \multicolumn{5}{|c|}{ Analyzed fatty acids (\% of fatty acids) } \\
\hline C16: 0 & 13.4 & 12.4 & 12.5 & 12.5 \\
\hline C16: 1 & 0.1 & 0.1 & 0.1 & 0.1 \\
\hline C18: 0 & 2.5 & 2.5 & 2.6 & 3.0 \\
\hline C18: 1 & 21.2 & 21.6 & 20.9 & 18.8 \\
\hline C18: 2 & 54.9 & 54.9 & 54.1 & 53.6 \\
\hline C18: 3 & 4.9 & 5.3 & 6.1 & 7.9 \\
\hline $\mathrm{C} 20: 4$ & 0.2 & 0.7 & 0.7 & 0.9 \\
\hline $\mathrm{C} 22: 6$ & 0.1 & 0.3 & 0.3 & 0.3 \\
\hline
\end{tabular}

${ }^{1}$ Composition of premix: Vitamin A 11,530 IU/kg; Vitamin D 2,400 IU/kg; Vitamin E $74.168 \mathrm{IU} / \mathrm{kg}$; Cu 24mg/kg; Fe 200mg/kg; Mg 122mg/kg; Se 0.38mg/kg; Zn $131 \mathrm{mg} / \mathrm{kg}$; Co $0.46 \mathrm{mg} / \mathrm{kg} ; \mathrm{F} 19 \mathrm{mg} / \mathrm{kg} ; \mathrm{I} 0.80 \mathrm{mg} / \mathrm{kg}$. 
Table 2. Chemical composition of broccoli floret residues

\begin{tabular}{|c|c|}
\hline Parameters & $\%$ \\
\hline \multicolumn{2}{|c|}{ Fatty acids (\% of fatty acids) } \\
\hline C12: 0 & 0.2 \\
\hline C14: 0 & 5.4 \\
\hline C15: 0 & 0.3 \\
\hline C16: 0 & 22.8 \\
\hline C16: 1 & 3.6 \\
\hline C18: 0 & 2.1 \\
\hline C18: 1 & 17.6 \\
\hline C18: 2 & 15.1 \\
\hline C18: 3 & 35.4 \\
\hline C20: 0 & 0.5 \\
\hline C22: 0 & 10.3 \\
\hline C24: 0 & 0.5 \\
\hline Fatty acids (\%) & 1.8 \\
\hline
\end{tabular}

Table 3. Effects of broccoli floret residue inclusion on egg yolk fatty acid composition ( $\%$ of fatty acids) ${ }^{1}$

\begin{tabular}{|c|c|c|c|c|c|c|c|}
\hline & \multicolumn{4}{|c|}{ Broccoli floret residue inclusion (\%) } & & \multicolumn{2}{|c|}{ Inclusion effect } \\
\hline & 0.0 & 4.0 & 8.0 & 12.0 & SEM & $\mathbf{L}^{2}$ & $\mathbf{Q}^{3}$ \\
\hline \multicolumn{8}{|l|}{ Saturated fatty acids } \\
\hline C14: 0 & $0.26^{\mathrm{a}}$ & $0.26^{\mathrm{a}}$ & $0.24^{\mathrm{b}}$ & $0.24^{\mathrm{b}}$ & 0.005 & 0.005 & $<0.001$ \\
\hline C16: 0 & $27.21^{\mathrm{a}}$ & $26.65^{\mathrm{b}}$ & $26.06 \mathrm{c}$ & $26.01^{\mathrm{c}}$ & 0.143 & $<0.001$ & 0.084 \\
\hline C18: 0 & 8.41 & 8.48 & 8.12 & 8.36 & 0.134 & 0.507 & 0.779 \\
\hline \multicolumn{8}{|c|}{ Mono-unsaturated fatty acids } \\
\hline C16: 1 & 2.55 & 2.35 & 2.11 & 2.14 & 0.12 & 0.423 & 0.633 \\
\hline C18: 1 & $38.76^{\mathrm{a}}$ & $38.65^{\mathrm{a}}$ & $36.13^{b}$ & $35.59^{b}$ & 0.282 & $<0.001$ & 0.412 \\
\hline \multicolumn{8}{|c|}{ Poly-unsaturated fatty acids } \\
\hline C18: 2n-6 & $17.50^{\mathrm{b}}$ & $18.74^{\mathrm{b}}$ & $22.27^{\mathrm{a}}$ & $22.03^{\mathrm{a}}$ & 0.48 & $<0.001$ & 0.138 \\
\hline C18: 3n-3 & $0.86^{\mathrm{c}}$ & $1.06^{\mathrm{b}}$ & $1.43^{\mathrm{a}}$ & $1.45^{\mathrm{a}}$ & 0.033 & $<0.001$ & 0.011 \\
\hline C20: $2 n-6$ & 0.18 & 0.16 & 0.20 & 0.19 & 0.03 & 0.004 & 0.199 \\
\hline C20: $3 n-6$ & 0.18 & 0.17 & 0.19 & 0.19 & 0.004 & 0.154 & 0.536 \\
\hline C22: 1 & $1.89^{\mathrm{ab}}$ & $1.87^{\mathrm{ab}}$ & $1.80^{\mathrm{b}}$ & $2.00^{\mathrm{a}}$ & 0.046 & 0.216 & 0.020 \\
\hline $\mathrm{C} 22: 6 \mathrm{n} 3$ & $1.07^{\mathrm{c}}$ & $1.19^{\mathrm{b}}$ & $1.20^{\mathrm{ab}}$ & $1.28^{\mathrm{a}}$ & 0.024 & $<0.001$ & 0.411 \\
\hline C24: 1 & 0.11 & 0.10 & 0.11 & 0.11 & 0.002 & 0.247 & 0.046 \\
\hline $\mathrm{SFA}^{4}$ & $35.87^{\mathrm{a}}$ & $35.40^{\mathrm{a}}$ & $34.50^{\mathrm{b}}$ & $34.61^{b}$ & 0.175 & $<0.001$ & 0.190 \\
\hline MUFA $^{5}$ & 43.20 & 42.86 & 40.04 & 39.73 & 0.294 & $<0.001$ & 0.985 \\
\hline PUFA $^{6}$ & $20.61^{b}$ & $21.41^{\mathrm{b}}$ & $25.39^{\mathrm{a}}$ & $25.26^{\mathrm{a}}$ & 0.314 & $<0.001$ & 0.165 \\
\hline SFA: PUFA & $1.75^{\mathrm{a}}$ & $1.66^{\mathrm{a}}$ & $1.36^{\mathrm{b}}$ & $1.38^{\mathrm{b}}$ & 0.025 & $<0.0001$ & 0.0675 \\
\hline
\end{tabular}

${ }^{\mathrm{a}-\mathrm{c}}$ Means in the same row with different superscripts are different.

${ }^{1}$ The values are means of 6 replicate cages

${ }^{2} \mathrm{~L}$ : Linear effect

${ }^{3} \mathrm{Q}:$ Quadratic effect

${ }^{4} \mathrm{SFA}^{3}$ : Saturated fatty acids

${ }^{5}$ MUFA: Mono-unsaturated fatty acids

${ }^{6}$ PUFA: Poly-unsaturated fatty acids 


\section{References}

1. Hu C, Zou A, Wang D, Pan H, Zheng B, et al (2011) Effects of broccoli stems and leaves meal on production performance and egg quality of laying hens. Animal Feed Science and Technology 170: 117-121.

2. Mustafa A, Baurhoo B (2018) Effect of feeding broccoli floret residues on leghorn layer performance and egg quality and nutrient digestibility. British Poultry Science 59: $430-434$

3. Campas-Baypoli ON, Nchez-Machado DS, Solano CB, Gaste'Lum JE, ReyesMoreno C, et al (2009) Biochemical composition and physicochemical properties of broccoli flours. Int J Food SciNutr 60: 163-173.

4. Jia W, Slominki BA, Guenter W, Humphreys A, Jones O (2008) The effect of enzyme supplementation on egg production parameters and omega-3 fatty acid deposition in laying hens fed flaxseed and canola seed. Poultry Science 87: 2005 2014.

5. Nain S, Renema RA, Korver DR, Zuidhof MJ (2012) Characterisation of the n-3 polyunsaturated fatty acid Enrichment in laying hens fed an extruded flax enrichment source. Poultry Science 91: 1720-1732

6. Huang S, Baurhoo B, Mustafa A (2018). Effects of extruded flaxseed on layer performance, nutrient digestibility, and yolk fatty acid composition. British Poultry Science 59: 463-469.

7. NRC (1994) Nutrient Requirements of Poultry, $9^{\text {th }}$ rev. ed. Nat. Acad. Press. Washington

8. O'Fallon JV, Busboom JR, Nelson ML, Gaskins CT (2007) A direct method of fatty acid methyl ester synthesis: Application of wet meat tissues, oils and feedstuffs. $J$ AnimSci 85: 1511-1521.

9. Zhuang H, Hildebrand DF, Barth MM (1995) Senescence of broccoli buds is related to changes in lipid peroxidation. J Agric Food Chem 4310: 2585-2591.

10. Murcia MA, Lo'pez-Ayerra B, Garc'1a-Carmona F (1999). Effect of processing methods and different blanching times on broccoli: proximate composition and fatty acids. LWT J Food SciTechnol 32: 238-243

11. Mustafa, A. and Baurhoo, B. (2017) Evaluation of dried vegetable residues for poultry: III Effects of feeding cabbage leaf residues on laying performance, egg quality, and apparent total tract digestibility. Journal of Applied Poultry Research, 27: $145-151$

12. Lopez-Bote CJ, Sanz Arias R, Rey AI, Castano A, Isabel B, et al (1998) Effect of free-range feeding on $\mathrm{n}-3$ fatty acid and $\alpha$-tocopherol content and oxidative stability of eggs. Anim Feed SciTechnol 72: 33-40

13. Mahfouz MM, Smith TL, Kummerow FA (1984) Effect of dietary fats on desaturase activities and the bio-synthesis of fatty acids in rat-liver microsomes. Lipids 19: 214-222.

14. Garg ML, Sebokova E, Wierzbicki A,Thomson AB, Clandinin MT (1988) Differential effects of dietary linoleic and $\alpha$-linolenic acid on lipid metabolism in rat tissues. Lipids 23: 847-852.

\section{Citation:}

A.F. Mustafa (2019) Feeding Broccoli Floret Residues on Layers: II. Effects on Fatty Acid Deposition. Integr J Vet Biosci Volume 3(1): 1-4. 